\title{
Krigens sår
}

Da den «store krigen» herjet i Europa, kom det medisinske artikler i franske tidsskrifter som ble oversatt og trykt i Tidsskriftet. Et eksempel omhandlet en ny metode for sårbehandling som gjengis her (Tidsskr Nor Lægeforen 1917; 37: 441-56). Artikkelen var illustrert med 30 figurer, og både antiseptisk behandling og lukking av sår blir beskrevet. En nøytralisert oppløsning av natriumhypokloritt, «Dakins opløsning», gjorde sterilisering enklere.

\section{Carrel og Dehelly: Behandling av inficerte saar}

Ref. av J. Åkerman i «Hygiea», mars 1917.

Oversat av A. Raabe.

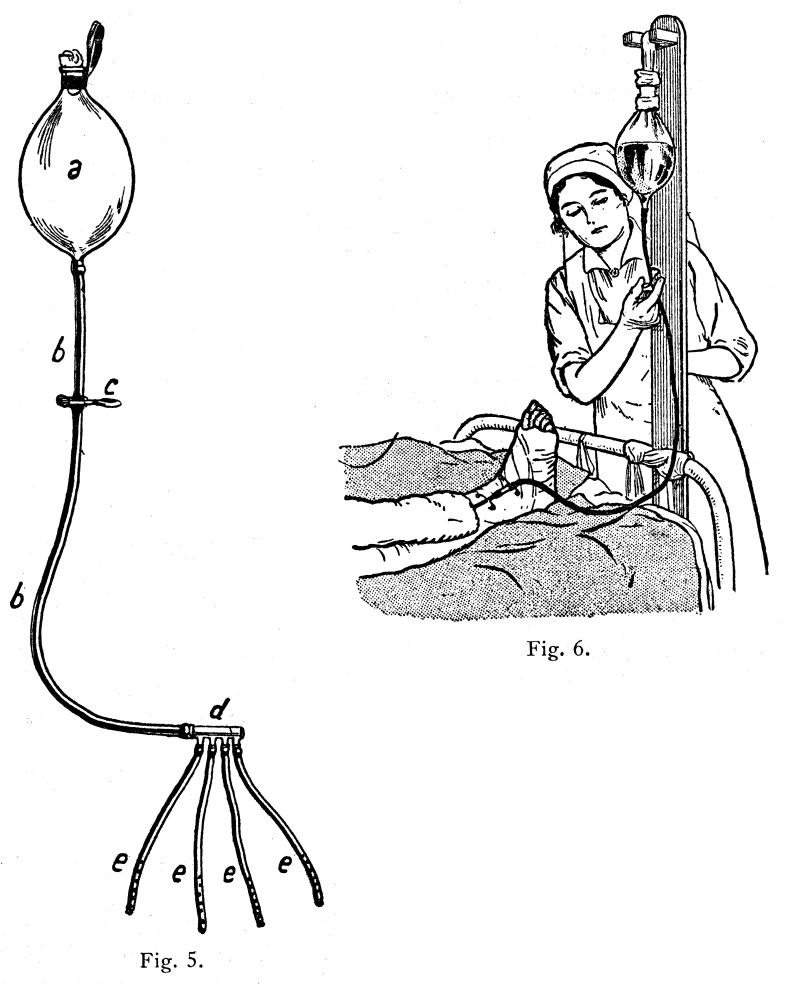

(..)

De første timer efter en skade viser saaret sig i almindelighet at være bakteriefrit. Efter 5-6 timer findes nogen mikroorganismer, men efter 12 timer en talrik bakterieflora og efter 24 timer det samme i saarets hele dybde. Fremmedlegemer som tøistykker og

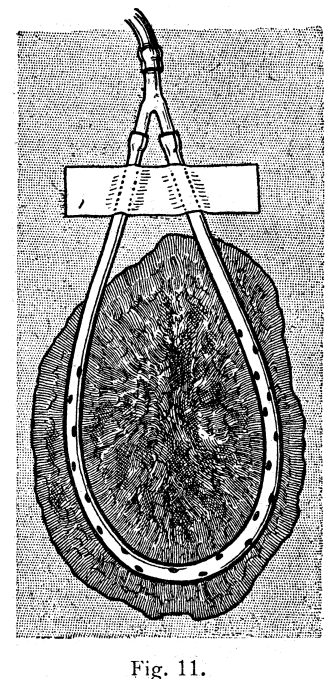

Anordning ved ytre saar.
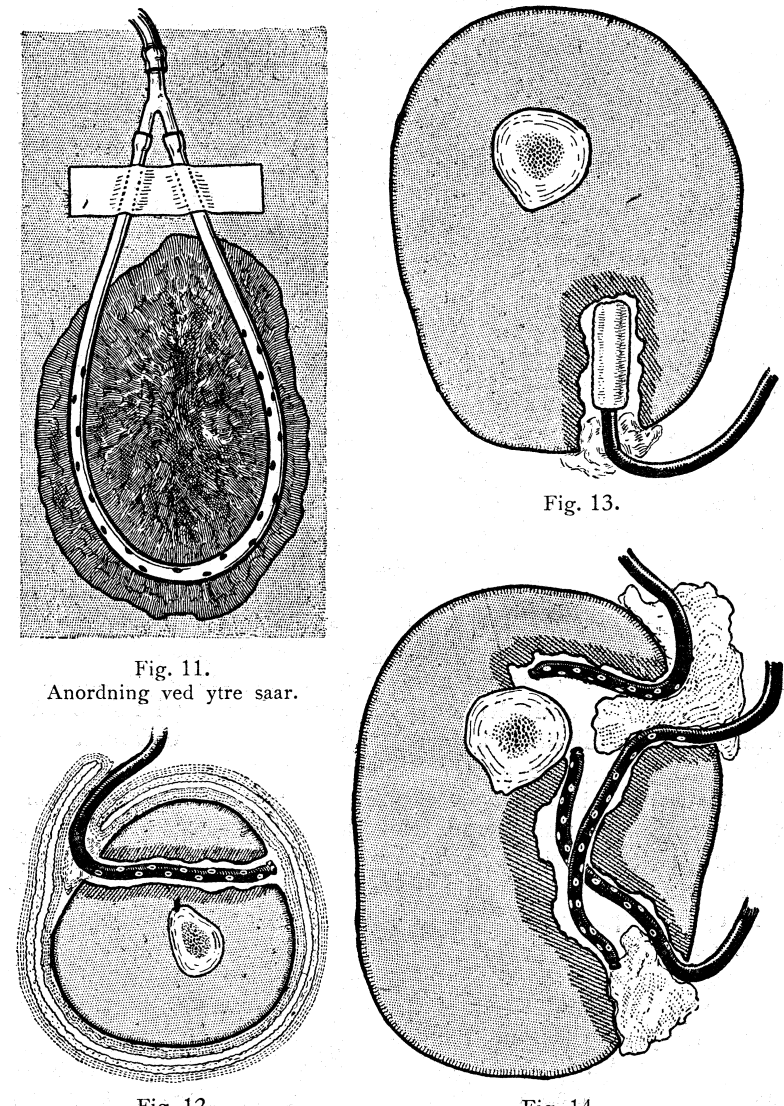

Fig. 13.

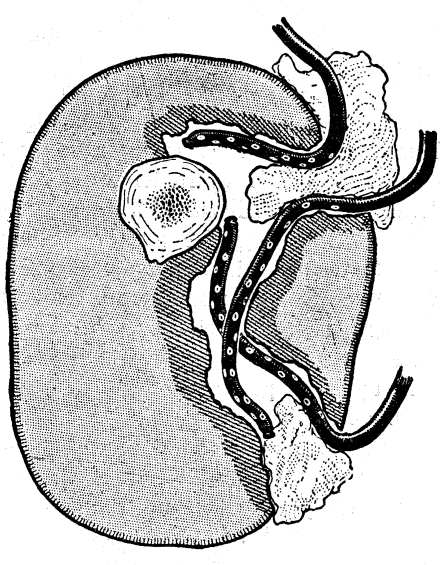

Fig. 14.

Drænrørene placeres saa væsken direkte træffer saaret. Ingen kompresser mellem drænrør og saar.

løse vævsdele øker bakteriefloraen. Naar Dakins opløsning bringes i kontakt med det inficerte saar, steriliseres dette for overfladiske saars vedkommende paa 24 timer, og hvor det gjælder dype, uregelmæssige saar paa 5-6 dage. Naar dette er opnaadd kan såret surureres. Hvis en sterilisation ikke opnaaes, beror dette paa, at væsken ikke hadde trængt ind i alle kroker av saaret. (...) 